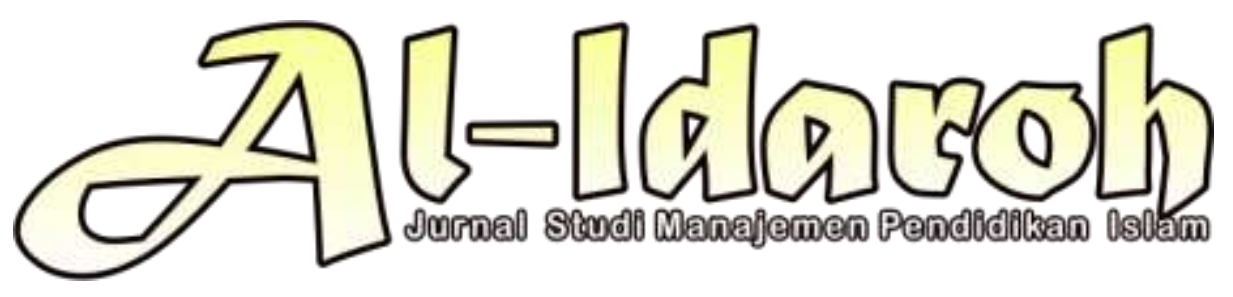

\title{
PERAN KEPALA MADRASAH SEBAGAI MANAJER DALAM PENINGKATAN EKSTRAKURIKULER KEAGAMAAN DI MTs AR-RAHMAN NGLABAN JOMBANG
}

\author{
Desy Naelasari \\ Sekolah Tinggi Ilmur Taarbiyah Al-Urwatul Wutsqo Jombang \\ Email: naelasaridesy@gmail.com \\ Sulastri Bin Abbas \\ Sekolah Tinggi Ilmur Taarbiyah Al-Urwatul Wutsqo Jombang \\ Email: sulastribinabbas15@gmail.com
}

\begin{abstract}
Abstrak: The head of the madrasa is not only a manager or leader, but the head of the madrasa also provides support to students so that they can take part in religious extracurricular activities in an orderly manner. As the head of the madrasa at MTs Ar-Rahman Nglaban Jombang who does not only carry out his duties and obligations as the head of the madrasa. However, increasing religious extracurricular activities (BTQ). The role of the madrasa principal as a manager in improving religious extracurricular activities at MTs Ar-Rabman Nglaban Jombang, focuses on religious extracurricular activities (BTQ), as well as the method used in BTQ religious extracurricular activities, namely the Iqra' method. Supporting factors for madrasah principals in increasing religious extracurricular activities are support from the school, parents, and the provision of adequate infrastructure. The inbibiting factor for the madrasah principal in increasing religious extracurricular activities is the lack of parental support, teachers who lack cooperation in religious extracurricular activities, and the students themselves
\end{abstract}

Keyword: Role, Extracurricular, Madrasah, 


\section{Pendahuluan}

Salah satu institusi pendidikan Islam yang memiliki kontribusi yang besar dalam pencerdasan kehidupan bangsa dan bernegara Indonesia adalah madrasah. Madrasah sejak berdirinya Nusantara telah memberikan pencerahan dan pencerdasan dalam mempersiapkan generasi bangsa yang cerdas dan Islami, terutama di bidang keagamaan. Madrasah kemudian menjadi lembaga pendidikan Islam yang dianggap sebagai era baru dari tahapan perkembangan institusi pendidikan Islam. ${ }^{1}$ Undangundang No.2 Tahun 1989 tentang pendidikan nasional telah mengakui keberadaan madrasah sebagai bagian dari sistem pendidikan nasional dan berdasarkan PP No.28 dan 29 Tahun 1989 ditetapkan bahwa madrasah adalah sekolah umum yang berciri khas Islam dan kurikulum madrasah adalah sama dengan kurikulum sekolah yang diakui. $^{2}$

Madrasah merupakan lembaga pendidikan yang bersifat kompleks dan unik. Bersifat kompleks karena madrasah sebagai organisasi yang di dalamnya terdapat berbagai dimensi yang satu dengan yang lain saling berkaitan dan saling menentukan. Adapun bersifat unik madrasah sebagai lembaga pendidikan memiliki ciri-ciri tertentu yang tidak dimiliki organisasi pendidikan lain. Madrasah juga memegang peran penting dalam proses pembentukan kepribadian anak didik. Peran madrasah dalam proses pembentukan kepribadian anak diantaranya yaitu melalui isi kurikulum, proses pembelajaran, dan penilaian, penanganan atau pengelolaan mata pelajaran, pengelolaan madrasah, pelaksanaan aktivitas, pemberdayaan sarana prasarana, pembiayaan dan etos kerja seluruh warga madrasah atau lingkungan. Melalui pendidikan madrasah diharapkan agar mereka para murid memiliki dua kemampuan sekaligus yaitu tidak hanya memiliki pengetahuan umum (iptek) saja tetapi juga memiliki kepribadian dan komitmen yang tinggi terhadap agamanya (imtak). ${ }^{3}$

Tanggung jawab yang paling besar di madrasah adalah posisi yang ada pada kepala madrasah sebagai seorang pemimpin dengan peran kepemimpinannya. Contoh peran kepemimpinan kepala madrasah antara lain kepala madrasah mengarahkan, memberi motivasi, dan mengambil keputusan agar para guru dan staf

${ }^{1}$ H. Gunawan, Kurikulum dan Pembelajaran Pendidikan Agama Islam, (Bandung: Alfabeta: 2012), 76. ${ }^{2}$ Undang-Undang Tentang Madrasah No.2 Tahun 1989, (Jakarta: Terayon Press, 1994), 90.

${ }^{3}$ M. Shulhan, Model Kepemimpinan Kepala Madrasah Dalam Meningkatkan Kinerja Guru, (Jogyakarta: Teras: 2013), 1-2. 


\section{Peran Kepala Madrasah Sebagai Manajer dalam Peningkatan Ekstrakurikuler \\ Keagamaan di MTs Ar-Rahman Nglaban Jombang}

lainnya di madrasah melaksanakan tugas dan tanggung jawab dengan sebaik-baiknya sehingga tercapai tujuan madrasah yang diingingkan. Kepala madrasah merupakan salah satu faktor yang sangat mempengaruhi gagal atau berhasilnya sebuah lembaga. Dengan kata lain berhasil tidaknya sebuah lembaga pendidikan dipengaruhi oleh faktor kepemimpinannya. Dengan demikian juga kepala madrasah sebagai pemimpin pendidikan seharusnya mampu mempengaruhi, mengajak, mendorong, memerintah, membimbing dan memaksa orang lain (guru) mau bekerja untuk mencapai tujuan dan menciptakan suasana iklim yang kondusif bagi tercapainya proses belajar mengajar didalam maupun di luar kelas.

Kepala madrasah sebagai pemimpin lembaga pendidikan yang bertugas menciptakan suasana kondusif yang ada dalam lingkungan kerjanya. Kondusif yang dimaksud di sini adalah kepala madrasah mampu menciptakan komunikasi dan hubungan sosial yang baik dengan semua warga sekolah, terutama dengan guru-guru, memfasilitasi sarana dan prasarana yang mendukung dan sebaignya. Suasana kondusif tersebut merupakan faktor yang terpenting dalam menciptakan guru yang berprestasi. Guru sebagai pendidik memilik peran yang sangat penting terhadap kemajuan bangsa Indonesia, guru juga sebagai salah satu faktor penentu keberhasilan pendidikan. Keberhasialn madrasah adalah keberhasilan kepala madrasah yang berhasil apabila memahami keberadaan madrasah sebagai organisasi yang kompleks, serta mampu melaksanakan peranan dan tanggung jawab untuk memimpin madrasah. ${ }^{4}$ Sebagaimana firma Allah Swt. adalah surah Al-Baqarah ayat 30:



${ }^{4}$ Wayosumijo, Kepemimpinan Kepala Sekolah, Tinjauan Teoritik dan Permasalahannya, (Jakarta: Raja Grafenda Persada: 2003), 81. 
Permasalahan kepala madrasah sangat penting terhadap maju dan tidaknya madrasah. Selain itu terdapat pula masalah yang terjadi pada peserta didik di madrasah, salah satu penyebabnya adalah semakin jauhnya peserta didik dengan ajaran agama. Khususnya pendidikan agama Islam di madrasah. Dalam waktu satu minggu mata pelajaran pendidikan agama Islam hanya mendapat dua jam dalam setiap pelajaran yaitu meliputi pelajaran Fiqih, Al-Qur'an Hadits, Aqidah Akhlak, Bahasa Arab dan SKI. Sehingga, dalam pendidikan agama Islam membutuhkan tambahan dalam bidang kegiatan keagamaan seperti ekstrakurikuler keagaman. Dengan adanya masalah tersebut maka peran kepala madrasah sangat dibutuhkan untuk mengatasi dan menanggulanginya.

Menurut Hotomo ekstrakurikuler diartikan juga kegiatan yang berada di luar program yang tertulis dalam kurikulum, seperti latihan kepemimpinan pembinaan siswa. Kegiatan ekstrakurikuler sangat penting diikuti bagi siswa dengan salah satu tujuannya yaitu, untuk meningkatkan pemahaman terhadap agama sehingga mampu mengembangkan dirinya sejalan dengan norma-norma agama dan mempu mengamalkan dalam perkembangan ilmu pengetahuan, teknologi, dan budaya. ${ }^{5}$

Untuk memperoleh hasil yang maksimal dari kegiatan ekstrakurikuler ini tentunya tidak lepas dari peran kepala madrasah dalam menjalankan salah satu dari fungsi kepemimpinannya yaitu pengawasan terhadap instansi yang dipimpin. Akan tetapi, harus menyadari bahwa setiap madrasah memiliki kelebihan dan kekurangan masinng-masing. Kelebihan dan kekurangan itu bisa dilihat dari segi manajemen/pengelolaan, kelengkapan sarana dan prasarana, pelatihan pemerintah, masyarakat terhadap madrasah, dan lain sebagainya. MTs Ar-Rahman mengarahkan kegiatan ekstrakurekuler yang menyentuh pada kegiatan yang mampu mempersiapkan siswa pada dunia kerja atau life skill (Jendral Kelembagaan Agama Islam, 2005).

Kenyataan dilapangan memang menunjukan bahwa kegiatan ekstrakurekuler mendapat proposal yang tidak seimbang, kurang mendapat perhatian, bahkan cenderung disepelekan. Perhatian madrasah-madrasah juga masih kurang serius, hal ini terlihat dari kurangnya dukungan yang memadai baik dari segi data, perencanaan, dan pelaksanaan, serta perannya sebagai bagian dari evaluasi keberhasilan siswa.

${ }^{5}$ Hoetomo, Kamus Lengkap Bahasa Indonesia, (Surabaya: Mitra Pelajar: 2005), 145. 


\section{Peran Kepala Madrasah Sebagai Manajer dalam Peningkatan Ekstrakurikuler \\ Keagamaan di MTs Ar-Rahman Nglaban Jombang}

Padahal dikalangan siswa banyak proses aktualisasi potensi siswa yang terjadi melalui kegitan ekstrakurekuler. Misalnya aktualisasi tentang kepemimpinan, kesenian, olahraga, kepekaan sosial, nilai religius, dan sebagainya sering muncul ketika ekstrakurekule. $^{6}$

Pelaksanaan kegiatan ekstrakurikuler keagamaan di MTs Ar-Rahman Nglaban Jombang, dikoordinasikan oleh siswa yang dibimbing oleh Pembina atau wali kelas masing-masing dengan bimbingan Kepala Madrasah MTs N 3 Boyolali. Berkembang atau tidaknya kegiatan ekstrakurikuler siswa di MTs Ar-Rahman Nglaban Jombang tidak lepas dari peran seorang kepala madrasah yang mempunyai tanggung jawab atas segala bidang kesiswaan, terutama pada ekstrakurikuler BTQ (Baca Tulis Al-Qur ${ }^{\text {ee }}$ ). Seorang kepala madrasah dapat dikatakan sebagai orang terdekat siswa yang memiliki peran dan upaya dalam mengembangkan kegiatan ekstrakurikuler BTQ di Madrasah. Sebagai pemimpin mengatur segala kegiatan di Madrasah dan salah satunya ekstrakurikuler BTQ ( Baca Tulis Al-Qurean). Mengingat begitu pentingnya kemampuan membaca Al-Qur'an bagi peserta didik dimana BTQ sangat berkaitan erat dengan mata pelajaran PAI yang didalamnya banyak menggunakan ayat AlQurean.

Peran kepala madrasah MTs Ar-Rahman Nglaban Jombang sudah menjalankan tugas dan tanggung jawabnya dengan baik. MTs Ar-Rahman Nglaban memiliki peserta didik yang cukup banyak dan memiliki karakter yang berbeda-beda. Karakter diantaranya yaitu ada antusias mendengarkan materi yang disampaikan guru, ada yang mendengarkan sambil bercanda, sambil makan, bahkan ada yang tidak mendengarkan sama sekali, dan sebaginya. Sebelum peserta didik mengikuti pelajaran khususnya pelajaran PAI banyak yang tidak dapat membaca Al-Qur'an dengan baik apalagi menghafal dan menulis huruf arab, namun dengan demikian adanya peran kepala madrasah yang mengadakan kegiatan ekstrakurikuler keagamaan, yaitu BTQ maka membantu kesulitan peserta didik untuk membaca dengan baik dan benar. Kemudian peserta didik sudah terbiasa membaca Al-Qur'an di pagi hari sebelum jam pelajaran dimulai. Hal ini tidak terlepas dari peran kepala madrasah yang membuat peserta didik berminat belajar Al-Qur'an.

'Peter Salaim, kamus Besar Bahasa Indonesia Kontemporer, (Jakarta: Modern English Press: 1991), 384. 


\section{Pembahasan}

\section{Peran Kepala Madrasah}

a. Pengertian Peran Kepala Madrasah

Peran menurut Mulyasa dapat didefinisikan sebagai suatu rangkaian perasaan ucapan, tindakan sabagai suatu pola hubungan unik yang di berikan oleh individu terhadap individu lain. ${ }^{7}$ Peran adalah seperangkat tingkah laku yang di harapkan orang lain terhadap seseorang sesuai kedudukanya dalam suatu sistem. Dari harapan-harapan ini seseorang kemudian akan bersikap dan bertindak atau berusaha untuk mencapai dengan cara dan kemampuan yang dimiliki. Oleh karena itu, peran juga dapat didefinisikan sebagai kumpulan harapan yang terencana seseorang yang mempunyai status tertentu. ${ }^{8}$

Sedangkan menurut Kompri menjelaskan bahwa kepala madrasah adalah tenaga fungsional guru yang diberikan tugas tambahan untuk memimpin suatu madrasah dimana diselenggarakan proses pembelajaran atau tempat dimana terjadi interaksi antara guru yang memberi pelajaran dan murid yang menerima pelajaran. Kepala madrasah merupakan salah satu komponen pendidikan yang paling berperan penting dalam meningkatkan kualitas pendidikan kepala madrasah bertanggung jawab atas penyelenggaraan kegiatan pendidikan, administrasi sekolah, pembinaan tenaga kependidikan lainnya, dan pendayagunaan serta pemeliharaan saran dan prasarana. ${ }^{9}$

b. Tugas dan Fungsi Kepala Madrasah

Menurut Mulyasa dalam Shulhan (2013: 48) kepala madrasah sebagai pemimpin lembaga pendidkan mempunyai tugas pokok dan fungsi dalam melaksanakan kegiatan pendidikan. Adapun penjabaran tentang peran kepala madrasah akan dijabarkan sebagai beriktu:

1) Kepala madrasah sebagai educator

Kepala madrasah melakukan tugas dan fungsinya sebagai educator, kepala madrasah harus memiliki strategi yang tepat untuk meningkatkan profesionalisme tenaga kepandidikan di madrasahnya. Sebagai educator,

${ }^{7}$ E. Muliyasa, Manajemen dan Kepemimpinan Kepala Sekolah, (Jakarta: Rajawali Press: 2012), 221. ${ }^{8}$ Abdulsyani, Sosiologi Skematika, Teori, dan Terapan, (Jakarta: PT Bumi Aksara: 2004), 94.

${ }^{9}$ Andang, Manajemen dan Kepemimpinan Kepala Sekolah (Konsep, Strategi, dan Inovasi Menuju Sekolah Efektif, (Yogyakarta: Gerbang Media: 2014), 54. 


\section{Peran Kepala Madrasah Sebagai Manajer dalam Peningkatan Ekstrakurikuler \\ Keagamaan di MTs Ar-Rahman Nglaban Jombang}

kepala madrasah harus senantiasa berupaya meningkatkan kualitas pembelajaran yang dilakukan oleh para guru.

2) Kepala madrasah sebagai manajer

Manajer adalah merencanakan, mengorganisasikan, mengatur, mengkoordinasikan dan mengendalikan dalam rangka mencapai tujuan yang telah ditetapkan. Dengan demikian, kepala madrasah harus mampu merencanakan dan mengatur serta mengendalikan semua program yang telah disepakati bersama. ${ }^{10}$

3) Kepala madrasah sebagai administrator

Kepala madrasah sebagai administrator harus memilik kemampuan untuk mengelola kurikulum, mengelola administrasi peserta didik, mengelola administrasi personalia, mengelola administrasin sarana dan prasarana, mengelola administrasi kearsipan, dan mengelola administrasi keuangan.

4) Kepala madrasah sebagai supervisor

Menjalankan tugasnya sebagai supervisor, kepala madrasah harus mampu melakukan berbagai pengawasan dan pengendalian untuk meningkatkan kinerja tenaga kependidikan. Pengawasan dan pengendalian juga merupakan tindakan preventif untuk mencegah agar para tenaga kependidikan tidak melakukan penyimpangan dan lebih berhati-hati dalam melaksanakan pekerjaannya.

5) Kepala madrasah sebagai leader

Kepemimpinan adalah salah satu kekuatan penting dalam rangka pengelolaan, oleh sebab itu kemampuan memimpin secara efektif merupakan kunci keberhasilan kepala madrasah. Selaian itu juga harus memberikan bimbingan dan mengarahkan para guru, staf dan siswa serta memberikan dorongan memacu dan berdiri di depan demi kemajuan dan memberikan inspirasi sekolah dalam mencapai tujuan.

6) Kepala madrasah sebagai Innovator

Kepala madrasah sebagai innovator akan tercermin dari cara-cara melakukan pekerjaannya secara konstruktif, kreatif, rasional dan obyektif,

${ }^{10}$ M. Shulhan, Model Kepemimpinan Kepala Madrasah Dalam Meningkatkan Kinerja Guru, (Jogjakarta: Teras: 2013), 1-2. 
pragmatis, keteladanan, disiplin, secara adaptable dan fleksibel, sekaligus mampu mencari, menemukan, dan melaksanakan berbagai pembaharuan di madrasah.

7) Kepala medrasah sebagai motivator

Kepala madrasah sebagai motivator harus memiliki strategi yang tepat untuk memberikan motivasi kepada para tenaga kependidikan dalam melakukan berbagai tugas dan fungsinya. Motivasi dapat ditumbuhkan melalui peraturan lingkungan fisik, pengaturan suasana kerja, disiplin, dorongan, penghargaan secara efektif, dan penyediaan berbagai sumber belajar melalui pengembagan pusat sumber belajar.

\section{Kepala Madrasah Sebagai Manajer}

a. Pengertian peran kepala madrasah sebagai manajer

Manajer adalah merencanakan, mengorganisasikan, mengatur, mengkoordinasikan dan mengendalikan dalam rangka mencapai tujuan yang telah ditetapkan. Dengan demikian, kepala madrasah harus mampu merencanakan dan mengatur serta mengendalikan semua program yang telah disepakati bersama. ${ }^{11}$ Ada tiga hal yang perlu diperhatikan dari tugas Kepala Sekolah sebagai manajer, yaitu proses, pendayagunaan seluruh sumber daya organisasi dan pencapaian tujuan organisasi yang telah ditetapkan. 1). Proses adalah suatu cara yang sistematik dalam mengerjakan sesuatu, 2). Sumber daya suatu sekolah, meliputi dana, perlengkapan, informasi,maupun sumber daya manusia, ayng masing-masing berfungsi sebagai pemikir, perencana, pelaku serta pendukung untuk mencapai tujuan, 3). Mencapai tujuan organisasi yang telah ditetapkan sebelumnya. Artinya bahwa Kepala Sekolah berusaha untuk mencapai tujuan akhir yang bersifat khusus (specific ends). Tujuan akhir yang bersifat spesifik ini tentunya tidaklah sama antara satu sekolah dengan sekolah yang lainnya.

b. Fungsi kepala madrasah sebagai manajer

Menurut Stoner sebagaimana dikutip Wahjosumidjo, ada delapan macam fungsi seorang manajer yang perlu dilaksanakn dalam organisasi, yaitu: a).

${ }^{11}$ Wahjosumidjo, Kepemimpinan Kepala Sekolah, (Jakarta: Raja Grafindo Persada: 2007), 83. 
Bekerja dengan dan melalui orang lain, b). Bertanggung jawab dan mempertanggung jawabkan, c). Dengan waktu dan sumber yang terbatas mampu menghadapi berbagai persoalan, d). Berpikir secara realistik dan konseptual, e). Seorang politisi, f). Seorang diplomat, g). Pengambil keputusan. $^{12}$

c. Standar kompetensi kepala madrasah sebagai Manajer

Pada tahun anggaran 2017, menteri Pendidikan Nasional Republik Indonesia mengeluarkan Standar Nasional Nomor 13 Tahun 2007 Tentang Kepala sekolah/madrasah Standar tersebut adalah sebagai berikut:

1) Menyusun perencanaan sekolah/madrasah untuk berbagai tingkatan perencanaan.

2) Mengembangkan organisasi sekolah/madrasah sesuai dengan kebutuhan.

3) Memimpin sekolah/madrasah dalam rangka pendayagunaan sumber daya sekolah/madrasah secara optimal.

4) Mengelola perubahan dan pengembangan sekolah/madrasah menuju organisasi pembelajaran yang efektif.

5) Menciptakan budaya dan klim sekolah/madrasah yang kondusif dan inovatif bagi pembelajaran peserta didik.

6) Mengelola guru dan staf dalam rangka pendayagunaan sumber daya manusia secara optimal.

7) Mengelola sarana dan prasarana dalam rangka pendayagunaan secara optimal.

\section{Ekstrakurikuler Keagamaan}

a. Pengertian Ekstrakurikuler Keagamaan

Menurut Badrudin (2014) kata ekstrakuler terdiri dari kata ekstra dan kurikuler. Ekstra artinya tambahan sesuatu di luar yang seharusnya dikerjakan, sedangkan kurikuler berkaitan dengan kurikulum, yaitu program yang disiapkan suatu lembanga pendidikan. Program tersebut berisi rumusan rencana dan pengaturan mengenai tujuan, isi, bahan pelajaran, dan cara yang di gunakan

${ }^{12}$ M. Shulhan, Model Kepemimpinan Kepala Madrasah Dalam Meningkatkan Kinerja Guru, (Jogjakarta: Teras: 2013), 1-2. 
sebagai pedoman penyelenggaraan kegiatan pembelajaran untuk mencapai tujuan pendidkan tertentu. ${ }^{13}$

Ekstrakurikuler keagamaan adalah upaya pemantapan dan pengayaan nilai-nilai, norma, pengembangan kepribadian, bakat, dan minat peserta didik pendidikan agama yang dilaksanakan di luar jam intrakurikuler dalam bentuk tatap muka atau non tatap muka (Peraturan Mentri Agama Nomor 16 Tahun 2010).

b. Metode Ekstrakurikuler Keagamaan Baca Tulis AlQur'an

Beberapa metode yang dapat dijadikan cara dalam belajar baca tulis AlQur'an menurut Ahmad Syarifuddin (2004: 81). ${ }^{14}$ Beberapa metode tersebut diantaranya adalah:

1) Metode Qira'aty

Metode Qira'aty disusun oleh H. Dahlan Salim Zarkasyi pada tahun 1986 bertepatan pada tanggal 1 juli. Sebagaimana yang diucapkan oleh H.M. Nur Shodiq sebagai penyusun dalam bukunya "sistem qoidah Qira'aty", metode ini adalah cara tepat membaca Al-Qur'an yang lebih menekankan pada praktek baca Al-Qur'an sesuai dengan qoidah ilmu tajwid.

Metode qiraáti adalah suatu cara penyampaian pelajaran kepada anak dengan tidak mengeja tetapi langsung membaca bunyi huruf yang ada di buku panduan qiraáti atau yang terdapat dalam Al-Qurán.dalam pengajran qiraáti terdapat beberapa petunjuk diantaranya: a). Mengajarkan langsung huruf hidup tidak boleh diuraikan, b). Guru cukup menjelaskan pokok pelajaran (atas sendiri dari setiap halaman) tidak boleh menuntun peserta didik dalam membaca, c). Guru cukup mengawasi dan menjelaskan apa-apa yang kurang, d). Apa bila dalam membaca peserta didik masih banyak yang salah maka harus diulang-ulang sampai bisa.

2) Metode Iqra'

Metode Iqra' adalah sebuah metode pengajaran Al-Qur'an yang menekankan langsung pada latihan membaca. Adapun buku panduan

\footnotetext{
${ }^{13}$ Badrudin, Mnajemen Peserta Didik, (Jakarta: Indeks: 2014), 146.

${ }^{14}$ A. Syarifudin, Mendidk Anak Membaca, Menulis, dan Mencintai Al-Qur'an, Jakarta: Gema Insani Press: 2004), 8.
} 


\section{Peran Kepala Madrasah Sebagai Manajer dalam Peningkatan Ekstrakurikuler \\ Keagamaan di MTs Ar-Rahman Nglaban Jombang}

Iqra'terdiri dari enam jilid di mulai dari tingkat yang sederhana. Tahap demi tahap sampai pada tingkat yang sempurna. Cara membacaAl-Qur'an dengan metode Iqra' ini pernah dijadikan proyek oleh Depertemen Agama RI sebagai upaya untuk mengembangkan minat baca terhadap kitab suci AlQur'an. ${ }^{15}$

Metode Iqro' terdiri dari 6 jilid dengan variasi warna cover yang memikat perhatian siswi-siswi. Metode pengajaran Iqro' adalah a). Baca langsung tanpa dieja, b). Cara belajar siswa-siswi aktif yaitu guru sebagai penyimak tidak menuntun hanya memberikan contoh pokok pelajaranya saja, c). Privat yaitu menyimak seorang demi seorang sedang bisa secara klasikal harus dilengkapi dengan peraga

c. Tujuan Kegiaran Ekstrakurikuler Keagaman

Secara khusus program ekstrakurikuler keagamaan ini bertujuan untuk memperdalam pengetahuan siswa mengenai materi yang diperoleh di sekolah,mengenai hubungan antara mata pelajaran keimanan dan ketakwaan serta sebagai upaya melengkapi pembinaan manusia seutuhnya. Sebagian di sebutkan dalam Al-Qur'an tentang anjuran kepada manusia untuk selalu menyeru pada kebaikan dan mencagah kepada yang murka. Seperti dalam firman Allah Swt, yang berbunyi:

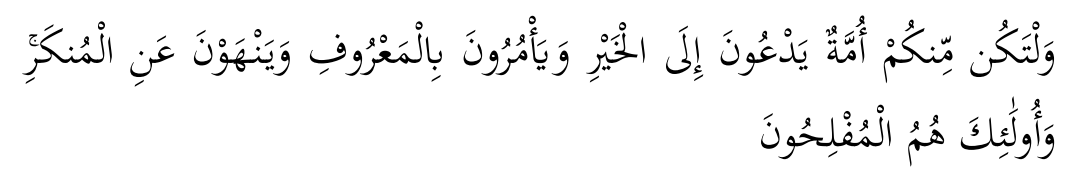

Artimya: Dan hendaklah ada di antara kamu segolongan umat yang menyeru kepada kebajikan, menyuruh kepada yang ma'ruf dan mencegah dari yang munkar; merekalah orang-orang yang beruntung. (Q.S Ali-Imran 3:104)

Adapun tujuan dari pelaksanaan kegiatan ekstrakurikuler di madrasah antra lain:

1) Meningkatkan dan memantapkan pengetahuan siswa

2) Mengembangkan bakat, minat, kemampuan dan keterampilan dalam upaya pembinaan pribadi

${ }^{15}$ M. Syaifullah, Penerapan Metode An-Nahdiyah dan Metode Iqro. Kajian ILmu Pendidikan, (Lampung: Iaim Numetro: 2018), 19 
3) Mengenal hubungan antara mata pelajaran dalam kehidupan di masyarakat. $^{16}$

Peraturan menteri Agama RI nomor 16 tahun 2010 tentan pengelolaan pendidikan agama pada sekolah/madrasah, bahwa tujuan ekstrakurikuler keagamaan adalah sebagai berikut:

1) Ekstrakurikuler pendidikan agama merupakan pendalaman, penguatan, pembiasaan, serta perluasan dan pengembangan dari kegiatan intrakurikuler yang dilaksanakan dalam bentuk tatap muka atau non tatap muka.

2) Pendalaman sebagaimana yang dimaksud merupakan pengayaan materi pendidikan agama.

3) Penguatan sebagaiamana yang dimaksud merupakan pemantapan keimanan dan ketakwaan.

4) Pembiasaan merupakan pengamalan dan pembudayaan ajaran agama serta perilaku akhlak mulia dalam kehidupan sehari-hari.

5) Perluasan dan pengembangan merupakan penggalian potensi, minat, bakat, keterampilan, dan kemampuan peserta didik di bidang pendidikan agama.

d. Jenis-jenis Ekstrakurikuler Keagamaan Baca Tulis Al-Qur' di Madrasah

Peraturan Direktur Jendral Pendidikan Agama Islam Nomor I,II/12 tahun 2017 pada sekolah/madrasah disebutkan jenis-jnis kegiatan ekstrakurikuler Pendidikan Agama Islam yaitu:

1) Pesantren Kilat (SANLAT)

Pesantren kilat merupakan kegiatan yang diselenggarakan pada watu bulan puasa yang berisi dengan berbagai bentuk kegiatan keagamaan seperti, buka bersama, pengkajian dan diskusi agama atau kitab-kitab tertentu, sholat tarawih berjamaáh, tadarus Al-Qur'an dan pendalamannya, dan laimn sebagainya. Kegiatan ini merupakan bentuk kegiatan intensif yang dilakukan dalam jangkatertentu yang diikuti serta penuh oleh peserta didik selam 24 jam atau sebagian waktu saja dengan

${ }^{16}$ L. Hafni, Pengembangan Kurikulum Menuju Kurikulum Berbasis Kompetensi, (Ciputat: Quantum Teaching: 2005), 76. 


\section{Peran Kepala Madrasah Sebagai Manajer dalam Peningkatan Ekstrakurikuler \\ Keagamaan di MTs Ar-Rahman Nglaban Jombang}

maksud melatih mereka untuk menghidupkan hari-hari dan malammalam bulan ramadhan dengan kegiatan-kegiatan ibadah.

2) Pembiasaan Akhlak Mulia (SALAM)

Program ekstrakurikuler dalam bentuk praktek pembiasaan akhlak mulia merupakan bagian dari kegiatan pembelajaran PAI yang dilakukan di sekolah atau di luar sekolah (keluarga dan masyarakat).

3) Tuntas Baca Tulis Al-Quran (TBTQ)

Merupakan kegiatan belajar membaca Al-Qur'an sesuai dengan kaidah-kaidah bacaan Al-Qur'an yang terangkum dalam ilmu tajwid serta belajar menulis huruf Al-Qur'an dengan benar.

4) Ibadah Ramadahan (IRAMA)

Ibadah ramadan merupakan aktifitas di bulan ramadhan, yaitu puasa ramadhan dan sholat tarawih.

5) Wisata Rohani (WISROH)

Wisata rohani merupakan kegiatan yang bertujuan untuk meningkatkan keimanan dan ketaqwaan kepada sang pencipta salah satunya yaitu melalui kegiatan tadabbur dan tafakkur alam yang mempunyai sasaran bagaimana tumbuh kesadaran pada diri peserta didik akan nilai-nilai Ilahiyah yang ada dibalik realitas keindahan alam semesta itu.

6) Kegiatan Rohani Islam (ROHIS)

Rohani Islam (disingkat Rohis) adalah sebuah organisasi memperdalam dan memperkuat ajaran Islam. Rohis sering disebut juga Dewan Keluarga Masjid (DKM). Rohis biasanya dikemas dalam bentuk ekstrakurikuler di sekolah menengah pertama dan sekolah menengah atas. Padahal fungsi Rohis yang sebenarnya adalah forum, pengajaran, dakwah, dan berbagi pengetahuan Islam. Susunan dalam Rohis layaknya OSIS, di dalamnya terdapat ketua, wakil, bendahara, sekretaris, dan divisi-divisi yang bertugas pada bagiannya masing-masing.

7) Pekan Keterampilan dan Seni (PENTAS)

PAI Pekan Keterampilan dan Seni merupakankegiatan yangdiselenggaraka dalam rangka melestarikan, memperkenalkan, dan 
menghayati tradisi, budaya, dan kesenian keagamaan yang ada dalam masyarakat islam. ${ }^{17}$

8) Peringatan Hari Besar Islam (PHBI)

Peringatan Hari Besar Islam (PHBI) adalah kegiatan-kegiatan yang dilaksanakan untuk memperingati dan merayakanhari-hari besar islam sebagaimana biasanya diselenggarakan oleh masyarakat islam di seluruh dunia berkaitan dengan peristiwa-peristiwa besar bersejarah, seperti Maulid Nabi Muhammad SAW., Isra' Mi'raj, peringatan 1 muharram, dan lain sebagainya.

Program keagamaan yang dapat dikembangkan dalam kegiatan ekstrakurikuler misalnya ekstra dakwah, tilawah Al-Qur'an, pengajian halaqoh, peringatan hari besar islam dan kegiatan-kegiatan agama lainnya. Atau juga dapat melalui program kegiatan keagamaan yang secara terintegrasi dengan kegiatan lain. ${ }^{18}$

Baca Tulis Al-Qur'an (BTQ) adalah suatu aktifitas yang mengajarkan atau memberikan bimbingan mengenai cara membaca dan menulis AlQur'an kepada peserta didik agar bahagia dunia dan akhirat. Adapun dasar Pembelajaran Baca Tulis Al-Qur'an dalam firma Allah Swt, yang berbunyi: surah Al-Alaq ayat 1-5:

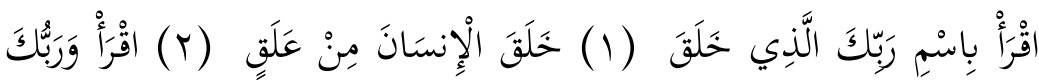

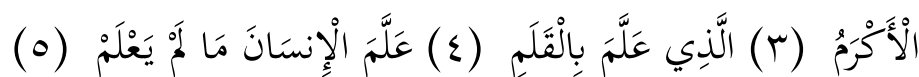

Artinya: Bacalah dengan (menyebut) Nama Tuhanmu Yang menciptakan. Dia telah menciptakan manusia dari segumpal darah. Bacalah, dan Tuhanmulah Yang Maha Pemurah. Yang mengajar (manusia) dengan perantaran kalam. Dia mengajar kepada manusia apa yang tidak diketahuinya. (Q.S Al-Alaq 96: $1-5)$

Ayat tersebut merupakan dasar perintah untuk membaca Al-Qur'an sekaligus merupakan wahyu yang pertama yang di terima oleh Nabi Muhammad SAW. Kata Iqro (bacalah) dalam dasar tersebut sebanyak dua kali. Mengungkap makna bahwa membaca harus dilakukan berulang kali

${ }^{17}$ D. Agama, Panduan Kegiatan Ekstrakurikuler, (Jakarta: Direktoral Jendral Agama Islam: 2005), 4

${ }^{18}$ H. Gumawan, Kurikulum dan Pembelajaran Pendidikan Agama Islam, (Bandung: Alfabeta: 2012), 76 
agar mampu membaca dengan dengan lancar. Perintah ini tidak hanya ditujukan kepada Nabi Muhammad SAW saja, tetapi juga perintah bagi para pengikut beliau. Membaca itu sangat penting, karena membaca merupakan pengantar manusia membuka jendela dunia. ${ }^{19}$

\section{Faktor pendukung dan penghambat kepala madrasah dalam peningkatan} ekstrakurikuler keagamaan

Pelaksanaan kegiatan ekstrakurikuler tentunya tidak mudah, hal ini dikeranakan banyak faktor yang dapat pendukung dan penghambat dari kegiatan ekstrakurikuler tersebut dapat berjalan dengan baik dan sukes.

a. Faktor pendukung

Adapun faktor pendukung dari kegiatan ekstrakurikuler keagamaan adalah sebagai berikut: 1). Tersedianya saran dan prasarana yang memadai. 2). Adanya semangat pada diri siswa, 3). Adanya tanggung jawab, 4). Memiliki manajemen pengelolaan kegiatan yang bagus, 5). Adanya komitmen dari kepala madrasah, guru dan siswa itu sendiri, 6). Adanya guru yang membimbing kegiatan tersebut. ${ }^{20}$

b. Faktor penghambat

Faktor penghambat dari kegiatan ekstrakurikuler keagamaan adalah sebagai berikut: 1). Adanya sarana dan prasarana yang kurang memadai, 2). Dalam pengelolaan kegiatan cenderung kurang terkoordinir, 3). Siswa kurang responsive dalam mengikuti kegiatan, 4). Tidak adanya kerja sama yang baik dari kepala madrasah, guru, dan murid itu sendiri, 5). Kurang adanya tanggung jawab, 6). Tidak hadirnya guru yang membimbing dalam pelaksanaan kegiatan tersebut

\section{Metode Penelitian}

1. Metode dan desain penelitian

Metode penelitian adalah cara yang digunakan oleh peneliti dalam mengumpulkan data penelitian dengan maksud untuk mencapai tujuan penelitian. Borg dan Gall (1989) dalam (Sugiyono, 2017) mengemukakan bahwa penelitian

\footnotetext{
${ }^{19}$ M. Syaifullah, Penerapan metode An-Nahdiyah dan Metode Iqra. Kajian Ilmu Pendidikan, (Lampung: Iaim Numetro: 2018), 26

${ }^{20}$ Jalaludi, Psikologi Islam, (Jakarta : PT Raja Grafindo Persada: 2012), 25
} 
berdasarkan jenis data terbagi menjadi dua yaitu kuantitatif dan kualitatif. ${ }^{21}$ Peneliti memilih metode penelitian kualitatif yang merupakan penelitian lapangan (field research) karena data yang dihasilkan berupa kata-kata tertulis atau lisan dari obyek dan perilaku yang dapat diamati. Penelitian kualitatif mengkaji perspektif partisipan dengan multi strategi yang bersifat interaktif, seperti observasi langsung, observasi partisipatif, wawancara mendalam, dokumen, teknik-teknik pelengkap, seperti foto kegiatan ekstrakurikuler, rekaman dan lain-lain. Desain penelitian adalah semua proses yang diperlukan dalam perencanaan dan pelaksanaan penelitian, mulai tahap persiapan sampai tahap penyusunan laporan. Desain penelitian yang digunakan dalam penelitian ini adalah desain deskriptif kualitatif.

2. Data dan Sumber Data

Teknik pengumpulan data merupakan langkah yang paling strategis dalam penelitian, karena tujuan utama dari penelitian adalah mendapatkan data. Berikut proses pengumpulan data yang akan dilakukan oleh peneliti yaitu dengan wawancara (Interview), Observasi dan dokumentasi.

\section{Diskusi Hasil Penelitian}

Berdasarkan hasil penelitian di atas, maka selanjutnya yang dilakukan yaitu melakukan diskusi hasil penelitian. Diskusi hasil penelitian dilakukan untuk menjawab rumusan masalah pada bab I. adapun yang akan di bahas pada diskusi hasil penelitian yaitu analisis peran kepala madrasah sebagai manajer dan kegiatan ekstrskurikuler keagamaan. Untuk mengetahui diskusi hasil penelitian tersebut, maka dapat dilihat sebagai berikut:

1. Peran kepala madrasah sebagai manajer dalam peningkatan ekstrakurikuler keagamaan (BTQ) di MTs Ar-Rahman Nglaban Jombang

Peran merupakan seperangkat tingkah laku yang di harapkan orang lain terhadap seseorang sesuai kedudukanya dalam suatu sistem. kepala madrasah MTs Ar-Rahman Nglaban Jombang sangat berperan penting dalam menjalankan tugas dan kewajibannya. Kepala madrasah mengadakan evaluasi kegiatan ekstrakurikuler BTQ dalam 4 bulan sekali jika kegiatan yang rasanya kurang berjalan efektif.

${ }^{21}$ Sugiyono, Metode Penelitian Pendidikan Pendekatan Kuantitatif, Kualitatif, dan R \& D. (Bandung: Alfabeta: 2017), 215. 


\section{Peran Kepala Madrasah Sebagai Manajer dalam Peningkatan Ekstrakurikuler \\ Keagamaan di MTs Ar-Rahman Nglaban Jombang}

Kepala madrasah juga harus mampu merencanakan mengatur semua program dan disepakati bersama.

Hal ini sesuai dengan teori Gaspersz (2003) kepala madrasah sabagai Manajer adalah merencanakan, mengorganisasikan, mengatur, mengkoordinasikan dan mengendalikan dalam rangka mencapai tujuan yang telah ditetapkan. Dengan demikian, kepala madrasah harus mampu merencanakan dan mengatur serta mengendalikan semua program yang telah disepakati bersama. Pelaksanaan kegiatan ekstrakurikuler BTQ sangat penting bagi siswa-siswi MTs Ar-Rahman Nglaban Jombang karena masih banyak siswa-siswi yang belum bisa baca AlQuran dengan baik dan benar. Belajar Baca Tulis Al-Qur,an akan menjadi pedoman dan bimbiangan hidup dunia dan akhirat.

Hal ini sesuai dengan teori Hasan (2005) ekstrakurikuler Baca Tulis AlQur'an (BTQ) adalah salah satu disiplin ilmu yang perlu diselenggarakan di seluruh lembaga pendidikan yang bernuansa islami. Adapun Tulis dalam kamus Besar Bahasa Indonesia diartikan sebagai membuat huruf, angka, dan sebagainya dengan pena, pensil, kapur dan sebagainya. Menulis disini tidak hanya sekedar membuat huruf, akan tetapi menulis disini dapat di artikan sebagai cara mengungkapakan sesuatu sampai menjadi tulisan di buku, di media massa, di blog dan sebagainya. Baca Tulis Al-Qur'an (BTQ) adalah suatu aktifitas yang mengajarkan atau memberikan bimbingan mengenai cara membaca dan menulis Al-Qur'an kepada peserta didik agar bahagia dunia dan akhirat.

2. Faktor pendukung dan penghambat kepala madrasah dalam peningkatan ekstrakurikuler keagamaan di MTs Ar-Rahman Nglaban Jombang.

a. Faktor pendukung

Faktor pendukung kegiatan ekstrakurikuler keagamaan di MTs ArRahman Nglaban Jombang yaitu persediaan sarana dan prasarana yang cukup memadai dan pengelolaan manajemennya cukup bagus. Selain itu, faktor pendukung lainnya adalah tim BTQ, memilih koordinator pengajar BTQ, dan guru-guru yang berpartisipasi ikut membantu mengkondisikan siswa-siswi untuk masuk kelas. Hal ini sesuai dengan teori Jalaludin (2012) faktor pendukung dalam kegiatan ekstrakurikuler BTQ yang ada di MTs Ar-Rahman 
terutama yaitu kepala madrasah, orang tua, guru dan siswa-siswi itu sendiri. Faktor pendukung yang lain yaitu persedian sarana dan prasarana yang cukup memadai dan manajemennya cukup bagus.

b. Faktor penghambat

Berdasarkan penelitian yang di lakukan oleh peneliti faktor penghambat yang terdapat di MTs Ar-Rahman Nglaban Jombang yaitu kurangnya dukungan dan kepedulian orang tua terhadap anaknya dan kurang kesadaran dari siswasiswi itu sendiri. Hal ini sesuai dengan teori Jalaludin (2012) sehingga siswasiswi banyak yang tidak mengikuti kegiatan ekstrakurikuler BTQ.

\section{Kesimpulan}

Kepala madrasah MTs Ar-Rahman Nglaban Jombang berperan sebagai manajer sudah menjalankan tugas dan tanggung jawabnya sebagai kepala madrasah sudah terlaksanakan dengan baik walaupun belum secara maksimal. Peran kepala madrasah MTs Ar-Rahman Nglaban Jombang dalam peningkatan ekstrakurikuler keagamaan BTQ yaitu menggunakan perannya sebagai manajer yaitu mengelolah, mengatur membimbing dan mengkoordinasi tenaga kependidikan sebagai salah satu tugas yang harus di lakukan oleh kepala madrasah. Kepala madrasah sebagai manajer mengadakan evaluasi empat bulan sekali dengan guru-guru. Peningkatan ekstrakurikuler keagamaan (BTQ) menggunakan metode tilawati (Iqra') yaitu sebuah metode pengajaran Al-Qur'an yang menekankan langsung pada latihan membaca yang mulai daei dasar membaca Al-Qur'an, yang bertujuan agar siswa dapat membaca Al-Qur'an dan memahami Al-Qur'an dengan baik dan benar sesuai makhrojal huruf dan kaidah-kaidah ilmu tajwid.

Faktor pendukung dalam peningkatan ekstrakurikuler keagamaan BTQ di MTs Ar-Rahman Nglaban Jombang yaitu: a). Sarana dan prasarana dan pengelolaan manajemen cukup bagus, b). Adanya pembentukan tim BTQ, c). Memiliki manajemen pengelolan kegiatan ekstrakurikuler BTQ cukup bagus. Sedangkan Faktor penghambat dalam peningkatan ekstrakurikuler keagamaan BTQ di MTs ArRahman Nglaban Jombang yaitu: 1). Kurangnya dukungan dari orang tua, dan kurangnya kerjasama dari pihak madrasah dalam kegiatan ekstrakurikuler keagamaan BTQ, 2). kurangnya kesadaran atau minat dari siswa-siswi itu sendiri. 
Peran Kepala Madrasah Sebagai Manajer dalam Peningkatan Ekstrakurikuler

Keagamaan di MTs Ar-Rahman Nglaban Jombang

\section{Daftar Pustaka}

Abdulsyani. Sosiologi Skematika, Teori, dan Terapan. Jakarta: PT Bumi Aksara: 2004.

Agama, D. Panduan Kegiatan Ekstrakurikuler. Jakarta: Direktoral Jendral Agama Islam, 2005.

Andang. Manajemen dan Kepemimpinan Kepala Sekolah (Konsep, Strategi, dan Inovasi Menuju Sekolah Efektif. Yogyakarta: Gerbang Media, 2014.

Badrudin. Mnajemen Peserta Didik. Jakarta: Indeks, 2014.

Gumawan, H. Kurikulum dan Pembelajaran Pendidikan Agama Islam. Bandung: Alfabeta, 2012.

Hafni, L. Pengembangan Kurikulum Menuju Kurikulum Berbasis Kompetensi. Ciputat: Quantum Teaching, 2005.

Hoetomo. Kamus Lengkap Bahasa Indonesia. Surabaya: Mitra Pelajar: 2005.

Jalaludi. Psikologi Islam. Jakarta: Raja Grafindo Persada, 2012.

Muliyasa, E. Manajemen dan Kepemimpinan Kepala Sekolah. Jakarta: Rajawali Press, 2012.

Salaim, Peter. Kamus Besar Bahasa Indonesia Kontemporer. Jakarta: Modern English Press: 1991.

Shulhan, M. Model Kepemimpinan Kepala Madrasah Dalam Meningkatkan Kinerja Guru. Jogyakarta: Teras, 2013.

Sugiyono. Metode Penelitian Pendidikan Pendekatan Kuantitatif, Kualitatif, dan R \& D. Bandung: Alfabeta, 2017.

Syaifullah, M. Penerapan metode An-Nahdiyah dan Metode Iqra. Kajian Ilmu Pendidikan. Lampung: Iaim Numetro, 2018.

Syarifudin, A. Mendidk Anak Membaca, Menulis, dan Mencintai Al-Qur'an. Jakarta: Gema Insani Press, 2004.

Undang-Undang Tentang Madrasah No.2 Tahun 1989. Jakarta: Terayon Press, 1994.

Wahjosumidjo. Kepemimpinan Kepala Sekolah. Jakarta: Raja Grafindo Persada, 2007. 